\title{
The Use of Deixis in Julia Gillard's Speech on Commemoration of Bali Bombing Victims in Garuda Wisnu Kencana Cultural Park, Bali
}

\author{
Dewa Ayu Marta Dewi ${ }^{1 *}$, I Ketut Wandia ${ }^{2}$, I Made Netra ${ }^{3}$ \\ ${ }^{[123]}$ English Department, Faculty of Arts, Udayana University \\ 1'[martadewi2@gmail.com], [2 [ketut_wandia@unud.ac.id], ${ }^{3}$ [dektih@yahoo.com] \\ *Corresponding Author
}

\begin{abstract}
This paper is entitled The Use of Deixis in Julia Gillard's Speech on Commemoration of Bali Bombing Victims in Garuda Wisnu Kencana Cultural Park, Bali. This research is aimed at analyzing the deixis used in the speech text by the Australia's Prime Minister, Julia Gillard using Levinson's theory. In conducting research, this study used qualitative method in which the study describes the types of deixis in which the data were taken from the Australian Minister website. Then identifying and classifying the deixis used in the speech text. The last step was analyzing the data supported by the concept of Levinson. From all the data analysis taken from the speech text delivered by Julia Gillard, this study found the types of deixis such as person deixis, time deixis, place deixis, discourse deixis, and social deixis. This study also found some deixis in one sentence which help the speaker and the audience understand the utterance better. This study suggests the students in the future to use the other part such as analyzing an interview, conference, novels, and the like. Finally, such a big hope for this study could be useful to sharpen the reader in understanding deixis.
\end{abstract}

Key words : deixis, types of deixis, pragmatics

\begin{abstract}
Abstrak
Karya ilmiah ini berjudul Deixis yang di gunakan dalam Pidato Memperingati Para Korban Bom Bali oleh Julia Gillard di Taman Budaya Garuda Wisnu Kencana, Bali (The Use of Deixis in Julia Gillard's Speech on Commemoration of Bali Bombing Victims in Garuda Wisnu Kencana Cultural Park, Bali). Karya ilmiah ini bertujuan untuk menganalisis deixis yang di gunakan dalam teks pidato oleh Perdana Menteri Australia Julia Gillard dengan menggunakan teory dari Levinson. Dalam melakukan analisis, penelitian ini menggunakan metode kualitatif dimana penelitian ini menjelaskan tipe - tipe dari deixis dan menggunakan data yang di ambil dari teks pidato. Langkah terakhir adalah menganalisis data yang di dukung dengan konsep dari Levinson. Dari analasis seluruh data yang diambil dari teks pidato milik Julia Gillard di temukan beberapa tipe deixis seperti person deixis, time deixis, place deixis, discourse deixis, dan social deixis. Penelitian ini juga menemukan beberapa deixis dalam satu kalimat yang membantu pembicara dan pendengar untuk lebih mengerti kalimat atau text yang sedang di bawakan. Karya ilmiah ini menyarankan untuk mahasiswa selanjutnya dapat menggunakan bagian lain seperti menganalisa interview, konferensi, novel, dan lain sebagainya. Besar harapan agar karya ilmiah ini dapat berguna untuk menajamkan pemahaman para pembaca mengenai deixis.
\end{abstract}


Kata kunci : deixis, tipe - tipe deixis, pragmatics

\section{Background of the Study}

Basically, discourse can be presented by two structural types; they are dialogue and monologue. Monologue or narrative is a discourse produced by only one participant and associated with the activities of writing and reading (Hatch, 1992: 209). When people use monologue or narrative the writer or the speaker is often confused to transfer the exact meaning of what they want to say. Much of the meaning is understood by looking at and perceiving what is hidden behind the linguistic markers that have a pointing 'function' in a given discourse context (Hatch, 1992).

Thus the writer and speaker can use a way in which the relationship between language and context is reflected in the structures of languages themselves, through the phenomenon of deixis. Levinson (1983:54) states that deixis is concerned with the way in which languages encode or grammaticalize features of the context of utterance or speech event, and thus it is also concerned with the ways in which the interpretation of utterances depend on the analysis of that context of utterance.

This view has motivated the writer to study deixis using the Julia Gillard's Speech on Commemoration of Bali Bombing Victims in Garuda Wisnu Kencana Cultural Park, Bali.

\section{Problem of the Study}

a. What types of deixis are found in the Julia Gillard's Speech?

b. How does context contribute to the meaning of the deixis found in the Julia Gillard's Speech?

\section{Aims of Study}

a. To identify the types and the dominant types of deixis used in the spoken speech text by Julia Gillard. b. To understand the context that contributes the meaning of the deixis

\section{Research Method}

Method is a systematic way to examine an object, which relates most suitable to research. Research on some narratives requires some steps. These steps are all necessary is determining the data source, method and technique of collecting data as well as method and technique of data analysis.

\subsection{Data source}

The data were taken from the text of the speech delivered by Julia Gillard in commemorating the terrorist attack in Bali. The text was downloaded from the website 3 pages long. This data source was chosen because the text itself consists of some types of deixis needed in this study.

\subsection{Method and Techniques in Collecting Data}

The method used in data collection is mainly the library research. This study used documentation method, including reading and note taking of the data from the speech text.

\subsection{Method and Techniques of \\ Analyzing Data}

The collected data were analyzed using qualitative method. Qualitative method is used because this research analyzed a textual material. It was also used to explain the analysis based on the theory for better understanding the Deixis phenomenon.

\subsection{Method and Techniques in Presenting Data}

The analysis would be presented in a formal way. It was presented descriptively. One by one the data presented along with the analysis based on the problems of the study using the 

Vol 22.4 Nopember 2018: 980-985

theory of deixis proposed by Levinson (1983).

\section{Result and Disscussion}

This chapter discusses the type of deixis used in speech or text, in this case in the Julia Gillard's speech in the commemoration of Bali bombing victims in Garuda Wisnu Kencana Cultural Park, Bali, proposed by Stephem C. Levinson (1983) in the book Pragmatics. The sub chapter proceeds to talk about the contextual meaning of the deixis using the study of semantics in analyzing the meaning of the context of deixis found in the speech text.

\subsection{Analysis of Types of Deixis}

According to Levinson (1983) in Pragmatics, there are 5 kinds of deixis; they are person deixis, time deixis, place deixis, discourse deixis, and social deixis. Here the analysis of deixis found in the Julia Gillard's Speech on Commemoration of Bali Bombing Victims in Garuda Wisnu Kencana Cultural Park, Bali.

\section{a) ONE TYPE OF DEIXIS IN A SENTENCE}

\section{1) Person Deixis}

And they did not die alone. 38 Indonesians died with them

Type of Deixis : Person Deixis

References : They refers to the Austalian victims of Bali Bombing. Them refers to the Australians who were dead in the Bali Bombing tragedy.

\section{2) Time Deixis}

This is a day of contesting emotions, from anger and

unamended loss to forgiveness and reconciliation with bitter past.

Type of Deixis : Time Deixis

Reference : This is a day

\section{3) Place Deixis}

88 Australians died here. Types of Deixis : Place Deixis

Reference : Here refers to Bali

\section{4) Discourse Deixis}

It was a time for leaders too.

Type of deixis : Discourse Deixis

Reference : It

5) Social Deixis

A place, like London and Gallipoli, where something of the Australian spirit dwell upon another shore.

Type of Deixis : Social Deixis

Reference : Dwells upon another shore

\section{b) TWO TYPES OF DEIXIS IN A SENTENCE}

1) Person Deixis + Time Deixis

Today, we gather to commemorate the worst terrorist attack our nation has ever known.

Types of deixis : Person Deixis and Time Deixis

References : Today refer to the day the speech being delivered. We refer to the Minister and the audience

\section{2) Person Deixis + Place Deixis}

And though our vigilance is greater, we have not surrendered the freedoms that brought us here in the first place 
Types of deixis : Person Deixis and Place Deixis

References : Our refers to the audience and minister. We refers to the audience and minister. $\boldsymbol{U} \boldsymbol{s}$ refers to the audience and minister. Here refers to the Garuda Wisnu Kencana Cultural Park

3) Person Deixis + Discourse Deixis

But even the debris fell, it was obvious the attack on our sense of ourselves - as Australians, as human beings - had failed.

Types of deixis: Person Deixis and Discourse Deixis

References : Our refers to the Australians. Ourselves refers to the Australians. It refers to the discourse referring to the terrorist attack.

\section{4) Person Deixis + Social Deixis}

With that strength, we

embrace those who suffered in Bali and lost so much.

Types of deixis : Person Deixis and Social Deixis

References : $\boldsymbol{W} \boldsymbol{e}$ refers to the audience.

Embrace as the social deixis

\section{5) Time Deixis + Discourse Deixis}

Ten years later and we witness today another sort of courage: the courage it has taken for the survivors and families to make this pilgrimage.

Types of deixis : Time Deixis + Discourse Deixis

References :Ten years later refers to the time. Today refers to the day the speech being delivered. It refers to the terorist attack
6) Time Deixis + Social Deixis

This is a day of contesting emotions, from anger and Unamended loss to forgiveness and reconciliation with a bitter past.

Types of deixis : Time Deixis and Social Deixis

References : This is a day refers to the time to rise up and wake up for the audience from the sadness.

Unamended loss

7) Place Deixis + Discourse Deixis

This is what the Bali Bombers struck at here.

Types of deixis : Place Deixis and Discourse Deixis

References : Here refers to the Bali island. This refers to the beauty and uncomplicated joy Bali island have.

\section{8) Discourse Deixis + Social Deixis}

Amid the horor, it was a time for heroes. Types of deixis : Discourse Deixis and Social Deixis References : It refers to the terrorist attack. Heroes

\section{c) THREE TYPES OF DEIXIS IN A} SENTENCE

\section{1) Person Deixis + Time Deixis + Place Deixis}

So today we return here in remembrance, but we also gather in quiet defiance.

Types of deixis : Person Deixis, Time deixis, and Place deixis

References : $\boldsymbol{W e}$ refers to the Minister and the audience. Today refers to the day the speech being delivered. Here refers to the place where the speech being delivered,Garuda Wisnu Kencana Cultural Park, Bali

2) Person Deixis + Place Deixis + Social Deixis Here in Bali, they 

Vol 22.4 Nopember 2018: 980-985

attacked our people and through them, sought to overwhelm our values.

Types of deixis : Person deixis, Place deixis, Social deixis

References : They refers to the terorist. Our refers to the minister and audience.Sought to overwhelm our values

\section{d) FOUR TYPES OF DEIXIS IN A SENTENCE}

1) Person Deixis + Time Deixis + Place Deixis + Discourse Deixis

Prime Minister Howard was a steadfast, reassuring voice for Australians in those dramatic days, and it is very fitting that he is here today.

Types of deixis : Person deixis, Place deixis, Discourse deixis

References : $\mathrm{He}$ refers to the Prime Minister Howard. Today refers to the day the speech being delivered. Here refers to Garuda Wisnu Kencana Cultural Park. Those refers to the day of the terorist attack. It refers to the Prime minister voices for the Australians

\subsection{Analysis of Contextual Meaning of Deixis}

Based on the analyzed data above the deictic expression on the speech text mainly talks about the Australian people and Indonesian whose families are being the victims in the Bali Bombing doing a commemoration for their love and won't forget them. There was not only one type of deixis found in one sentence in this study but also two until three types of deixis in one sentence. The deixis could help the speaker deliver the meaning of a sentence thus the speaker can use more than one deixis in a sentence to refer to the meaning well.

\section{1) Person Deixis}

As it is shown above, the Minister mostly used first person deixis during her speech. In detail, the most used first person deixis is the first plural nouns we and our. The Minister mostly uses these words as she represents all the Australian and Indonesian citizens in the speech. Moreover, he also uses those words to show that she put herself as one of the Australian citizens who some of them were the victims of Bali Bombing tragedy.

Furthermore, the third person deixis, such as they, them are also used when the Minister explains how the terrorist attack happened and frightened the people in Bali and the tourist who wanted to come to Bali. The words are used to refer to the terrorist who was not in the commemoration.

\section{2) Time Deixis}

In the speech the Minister mostly used the type of time deixis today. The Minister tries to deliver the spirit and to awake the familis who lost their loved ones in the bombing accident that today is the time to rise and fight against the terrorist together. The deictical word today is also used to express that it was grateful they can gather to commemorate the incident. The minister also uses the types of time deixis before and later in some sentences. Before is used to emphasize that both countries Indonesia and Australian have never been this close, that the accident has made them closer and together gaining some courage and fight against the terrorist.

\section{3) Place Deixis}

During the speech the Minister mostly used the types of the place deixis here. The Minister used it almost all of the time to make the audience more focus on her speech. Here in the speech refers to the place where the Prime Minister Julia Gillard is speaking, 

Vol 22.4 Nopember 2018: 980-985

Garuda Wisnu Kencana Cultural Park. However, the dectical word here in the speech also refers to the bustling streets which mean the busy place or busy city like Bali where the place was targeted by the terrorists. Beside here the Minister rarely used the other place deixis such as there, this, and that.

\section{4) Discourse Deixis}

In the speech the Prime Minister Julia Gillard mostly used Discourse Deixis expression it and lastly used these and this. It is mostly used by the Minister in her speech. The word it here refers to the bomb attack, the time the terrorist attacking Bali with the bomb, and the terrorist itself.

\section{5) Social Deixis}

Social deixis is particular aspects of the social relationship holding between the speaker and addressee(s) or speaker and some referents. Obvious examples of such grammaticalizations are 'polite' pronouns and titles of address. The Prime Minister Julia Gillard in her speech of commemoration of the Bali Bombing victim also used some social deixis expressions. The reason she used the social deixis in her speech was to deliver her speech in a more polite manner. Because it was still in a mourning situation, the Minister wanted to show her big condolences to the survivors and the family who were left by the Bali Bombing victims.

\section{Conclusion}

Based on the foregoing analysis and discussion, the following points can be drawn as conclusions:

Person deixis functions to represent the victims, the terrorist, the family, and the audience. Therefore, by using the person deixis it will make the audience understand the message easier. The person deixis mostly used by the Prime
Minister is the first plural noun $W e$ and Our, because the Prime Minister Julia Gillard wanted to persuade the audience to wake up and stand up against the terrorist. Time deixis is used to point to a time of the event relative to the time of speaking, the Prime Minister mostly used today. place deixis indicates the location between the speaker and the listener or the audience, including the locative Here. Discourse deixis is a number of other ways in which an utterance signals its relation to surrounding text such as in the speech text mostly used It. social deixis is a particular aspect of the social relationship holding between the speaker and addressee(s) or speaker and some referents.

\section{Bibliography}

Anonymous.https://www.theaustralian.c om.au accessed on October $28^{\text {th }}$ 2018

Hatch, Evelyn. 1992. Discourse and Language Education. Cambridge. Cambridge University Pers,

Levinson. S. 1983. Pragmatics. Cambridge: Cambridge University Press. 